\title{
LO URBANO, LA PROPIEDAD Y LA PRODUCCIÓN LEGISLATIVA EN BOLIVIA: UNA LECTURA
} DESDE EL DERECHO URBANÍSTICO

\section{Juan E Cabrera}

\section{RESUMEN}

Este trabajo recorre el conjunto de instrumentos legales urbanístico-territoriales de escala nacional desarrollados en Bolivia entre los años 1871 y 2016. Centra su atención en una serie de normas organizadas en función a regímenes del Derecho Urbanístico, caracterizados por el tratamiento de los derechos de propiedad del suelo. Exhibe la presencia de leyes interventoras entre 1930 y 1950 y la postergación del tema la década de 1960. Asimismo, expone la reconsideración de esta discusión entre las décadas de 1970 y 2000, confirmando el cambio de enfoque de legislación luego de 1985. La importancia del trabajo radica en que el contenido permitirá conocer y reflexionar sobre el devenir de la legis lación urbana en Bolivia, así como orientar las acciones en una futura política urbana. Esto, a través de poner en la discusión, no sólo la necesidad de leyes urbanas, sino de legislación urbanística centrada en la propiedad y la redistribución equitativa de cargas y beneficios de la urbanización.

Palabras Clave: Derecho Urbanístico, Legis lación Urbana, Propiedad, Función Social, Bolivia.

DOI: $10.23881 /$ idupbo.018.2-8e 